\title{
Myles Brand's Philosophy of the Value of Intercollegiate Athletics: A Collaborative Effort and the Perspective of Two Black Males on Educational Achievement at the NCAA
}

\author{
C. Keith Harrison ${ }^{1}$, Bernard Franklin², and Whitney Griffin ${ }^{3}$ \\ 1 University of Central Florida \\ ${ }^{2}$ National Collegiate Athletic Association \\ ${ }^{3}$ Cerritos College
}

"There is no better place to learn life skills than athletics." (Myles Brand, 2008)

\section{Phase One Interaction with Myles Brand: The Conference}

In August of 2003, the National Collegiate Athletic Association (NCAA), the Black Coaches Association (BCA), educators, scholars, and athletic administrators were in attendance at a hotel in Kansas City, Missouri. At this particular conference, I (first author of this paper) was afforded the opportunity to investigate the inequities of ethnic minority coaches at the collegiate level after I had presented on how my research team would approach this important topic. I was lucky enough during the working groups to be assigned to Dr. Myles Brand's team. As a think tank of leaders, our mission was to do our best to figure out how to address these diversity, equity, and inclusion issues in both a philosophical and practical manner. Serendipitously, I had another topic in my intellectual queue related to education and sport that I would later pose to Myles during our think tank. Before diving into the second interaction with Myles, it is crucial that this paper be positioned within the personal narrative theory in order to analyze the philosophical aspects of education, sport, and the body.

\section{Personal Narrative Theory}

Universal to human development, personal narratives give life to theory and practice. Personal narratives are not confined to the field of sociology; they are also prominent in social science fields and sub-fields such as personality psychology (McAdams, 2008). The last two decades have seen the analysis of personal narra- 
tive research cross intellectual boundaries and connect with nearly every academic discipline in the United States (Kohler-Riessman, 2001). One of the advantages of personal narrative theory is the ability to investigate the connections within and between multi-layered chronicles at one time:

Personal narratives can address several key theoretical debates in contemporary sociology: macro and micro linkages; structure, agency, and their intersection; process of structuration; social reproduction and social change. They can provide access to both the individual and the social, and make it possible to see connections between them - and are shaped by relations of production and power, systems of language, symbols, beliefs, and cultures, as well as histories and geographies (Laslett, 1999, p. 392).

The connective tissues of education, race, and sport have illuminated theoretical scholarship on how relations of production and power affect Black male college athletes in football and basketball. Persistent inquiry into the layered systems of language, beliefs, cultures, and histories for this demographic is incumbent upon scholars in order to address the challenges relevant to their educational experiences.

Sustainable solutions to diversity, equity, and inclusion for Black male athletes should engage multiple levels of a students' ecology. For example, macro-level factors could include American cultural values towards Black males and football, meso-level factors could include faculty communication with the students, and micro-level factors could examine a Black male athletes' friendships, family, activities, and teachers (Bronfenbrenner, 1979). Scholars in the intersection of education, race, and sport (especially with African American college athletes in football and men's basketball) are urged to consider that:

Future research should extend the work presented here by focusing on more in-depth case study narratives on some of the macro-, meso- and micro-level factors affecting the educational experiences and holistic developmental opportunities of African American male athletes (past and present) in secondary and postsecondary educational settings. In addition, other qualitative approaches such as critical ethnography, participatory action research, grounded theory, and phenomenological research could help expand what we know about the educational issues and challenges facing this student population. (Singer, 2016, p. 1091)

As such, this paper follows the emergence and value of the personal narrative by two African American males working together within the structural forces of the NCAA, higher education, and intercollegiate athletics. The combination of these three structures is in strong alignment with Myles Brand's integrated view of education and sport. As Brand (2006) stated,

The idea of harmony between mind and body in education comports well with the underlying philosophy of education in this country . . . The Integrated View disposes of the bias against physical-skill development. The Attic Greeks had a good perspective. They believed that the mental and the physical should both be part of a sound education. Even someone as 
committed to the superiority of the mental as Plato held that physical accomplishment was necessary for successful citizenship (p. 17).

Brand's reference of Plato's philosophy illustrates the harmony of education and sport, academics and athletics in concert as one integrated identity, to improve academic standards. The next section is phase two of the personal narrative in real time of one such collaboration. The following story is about two individuals who believed that an innovative program approach to harmonize education and sport through visual representation could synergize intercollegiate athletics and American higher education in a unique way.

\section{Phase Two Interaction with Myles Brand: Scholar-Baller ${ }^{\circledR}$}

\section{First Author}

\section{Background on Scholar-Baller and the Many Educational Wins}

During the roll out of the BCA Hiring Report Cards, I asked Myles, "Is it possible to have an academic patch on the front of the jerseys during athletic competition?" Myles directed me to see Kevin Lennon and JoJo Rinebold, two NCAA senior leaders. One of them asked if Scholar-Baller TM was trademarked. "Yes," I confidently replied. Consequently, Myles asked me to speak to Dr. Bernard Franklin (one of the top senior leaders at the NCAA during this time period) about how Scholar-Baller might fit with the Academic Progress Rate (APR) movement and the Committee on Academic Performance.

Bernard was a key leader for our nonprofit organization and he taught me that you have advocates or acquaintances - Bernard was the former. Once Bernard and I connected, he offered encouragement that my timing was spot on and had great potential to build a partnership based on the leadership vision of Myles' improved academic performance outcomes. What jump started the timing was that Myles and Bernard had been conversing about diversity, equity, and inclusion already. Myles was curious how African American communities perceived intercollegiate athletics in terms of African American men and women in higher education. Bernard explained that there was discussion of a strategy on this topic to potentially partner with the United Negro College Fund (UNCF), whose motto "A mind is a terrible thing to waste" appeared to fit perfectly. Bernard and I both agreed that the UNCF's motto coupled with the cool, edgy language of Scholar-Baller had the potential to impact all student-athletes, especially African American collegiate athletes.

Today, the Scholar-Baller program synergizes intercollegiate athletics and American higher education. The mission of this non-profit organization is "To inspire youth and young adults to develop leadership skills and to excel in education and life by using their cultural interests in sport and entertainment" (scholarballer.org, n.d.). In support of the mission, the vision statement is "To systematically recognize and reward all student-athletes who excel academically in order to further their academic 
and personal development" (scholarballer.org, n.d.). Some of its initiatives include the Academic Performance Recognition Incentive ${ }^{\text {TM }}$, the Scholar Baller ${ }^{\circledR}$ Education Station at the Dwight Howard Basketball Camp (2009-2012), and the Academic Momentum Award TM. Over 1,000 scholar athletes are recognized annually through the "SB Patch" which is typically worn on game jerseys, hats, and other pieces of apparel. Other forms of recognition incentives include helmet stickers, plaques, and honor roll placement for their academic performance. New incentives will continue to be introduced on a regular basis to provide cool and functional items in recognition of one's dual achievement on both the playing field and in the classroom.

Using a three-pronged approach, Scholar-Baller program targets education (i.e., curriculum), research (i.e., measurement of impact), and mentoring (i.e., peer groups). As a tool, the culturally relevant curriculum is based on the six ideals of vision, industry, self-respect, perseverance, success, and humility. The innovative curriculum has led to measured positive impact, as many Scholar-Baller participants have seen a boost in individual and team GPAs, as well as APR scores across race, gender, and social class populations (Harrison et al., 2018; 2020; Harrison \& Bukstein, 2015; Harrison \& Rasmussen, 2015; Harrison \& Sutton, 2013). Finally, mentoring is facilitated through partner programs that range from high schools to community colleges to universities to professional players in the National Football League.

In the next section, Bernard takes us on the journey of these theoretical discussions to the eventual approval by Myles to fund a Scholar-Baller initiative through the NCAA and the many schools that would benefit from this governing body of intercollegiate sports' stamp. After we received the green light, Bernard brings us to his phone call with me on November 20, 2005 to share the great news that Myles wrote the following approval note with a phrase he always told me about Scholar-Baller's educational and academic message: "It's about pride." I pass the mic to the second author of this paper at this juncture of the essay.

\section{Second Author}

My first introduction to Scholar-Baller was early in my tenure at the NCAA national office. I accompanied President Myles Brand to a People United to Save Humanity (PUSH) national convention, where Reverend Jesse Jackson was hosting a roundtable discussion on intercollegiate athletics and Dr. Brand was a panelist. As I recall, there was significant discussion regarding African American student athletes with a focus on Division I football and men's basketball. Dr. Brand was peppered with questions and comments about the low graduation rates for Black student athletes. Myles took the position that the issues being presented had to be addressed and he indicated that one of his foci was dedicated to improving the academic performance of not just Black student-athletes, but all student-athletes.

It was at this roundtable discussion where I first met Keith. He briefly introduced a program to me he had developed that aimed at improving the academic performance of student-athletes. His approach to improving the academic performance of student-athletes was rather unique and the branding concept was considered a little edgy and unorthodox. The nomenclature "scholar-baller" was raw but generational. That said, it was somewhat difficult for some NCAA staff members to embrace it at 
that time.

Both Dr. Brand and I were intrigued by the programmatic approach of Scholar-Baller and I arranged for Keith to meet with staff members who were engaged in developing the Academic Performance Plan. As I listened to Keith outline the tenets of the Scholar-Baller initiative, I was struck by what I perceived as the two foundational cornerstones of his initiative: identification and recognition. It was clear to me that student-athletes who would become involved in this initiative would identify the appropriate strategies to assist them in achieving an established academic goal. Second, once a student-athlete achieved the goal for academic success, there was a process for public recognition and affirmation.

Keith's approach was a confluence of hip-hop culture and an emphasis on attainable academic achievement. The term "baller" in hip-hop culture denotes an athlete who is skilled and experienced in playing the "game." It was a term that young student-athletes could relate to and identify with. I thought of it as a refreshing approach to defining the concept of winning beyond the field of athletic competition to include achieving in the academic classroom.

The timing of Keith's discussions with myself and NCAA staff was fortuitous because it came as President Brand was ushering in an era of renewed emphasis on the academic achievement of student-athletes. This emphasis led to the establishment of the Division I Academic Performance Program (APP), which created

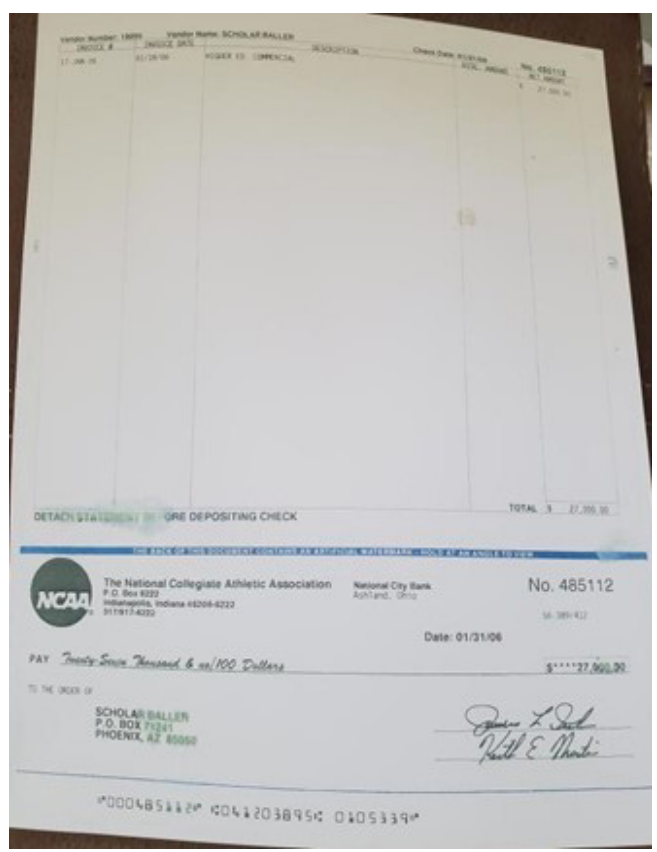

Figure 1

Image of NCAA Support

Note: Original image used from the first author's collection. penalties and sanctions for teams who did not meet certain academic benchmarks.

Even though it was not a conventional approach, I thought the Scholar-Baller concept was worth supporting. That is exactly why I thought the NCAA should support the program: because it was unconventional and spoke to student-athletes, particularly African American student-athletes, on a level they could relate to in a dynamic way. President Brand had a similar mindset and authorized a start-up grant to take Scholar-Baller from being a concept on paper and transforming it into a programmatic reality (see Figure 1).

Dr. Brand plowed new ground and invested in an idea that has benefited many student-athletes. He supported a concept that not only makes school cool, but also 
represents how cool education and academic performance is through the Scholar-Baller logos that are gender inclusive and available to every NCAA competitive sport (see Figures 2 and 3 taken from scholarballer.org).

These artistic images harmonize education and sport through visual representation in a unique way.

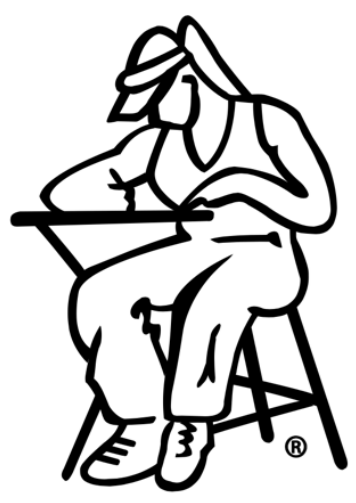

Figure 2

Image of Scholar-Baller ThinkWoman Logo

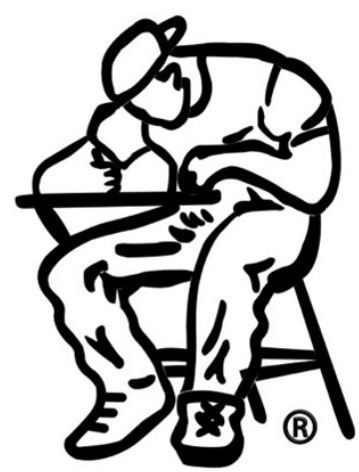

Figure 3

Image of Scholar-Baller ThinkMan Logo

\section{Discussion: A Note on "Theory in Practice" of the Scholar-Baller Concept Guided in Part by Somaesthetics}

Philosophers of sport have contributed a great deal to the literature on the body and human movement. While not exhaustive, some of the key scholarship in this philosophical context includes an analysis of dualism (Kretchmar, 1994), perceptions of athletic bodies (Weiser, in press), and aesthetics of the body (Shusterman, 1999). The specific area of body scholarship within the philosophy of sport community provides an ideal lens to evaluate the linkage of education and sport.

The value of the Scholar-Baller program and logos align with Brand's vision of improving academic standards through its images and culture of self-fashioned achievement. Such bodily perception, performance, and presentation of the Scholar-Baller initiative require an interdisciplinary field of inquiry to fully dissect it. Sport philosophers refer to this field of analysis as somaesthetics. According to Shusterman (1999),

Somaesthetics can be provisionally defined as the critical, meliorative study of the experience and use of one's body as a locus of sensory-aesthetic appreciation (aesthesis) and creative self-fashioning. It is therefore also devoted to the knowledge, discourses, practices, and bodily disciplines that structure such somatic care or can improve it. (p. 302)

In keeping with Scholar-Baller's thematic curriculum of six ideals, somaesthetics has six components: pragmatic, experiential, analytical, practical, representation- 
$a l$, and performative. Representational and performative are most associated with Scholar-Baller's sport and body project that moved the needle through Myles Brand and the NCAA's support. Honor rolls, car bumper stickers about high academic achievers, and scholar-athlete Academic All-American recognition messages have been around for many years. However, the innovation gap that Scholar-Baller filled was maximizing the symbols of education and sport performance through language and the artistic creativity of popular culture. This is why Scholar-Baller has two main representations of academic excellence (3.0 grade point average or higher): the ThinkMan and ThinkWoman.

The genesis of Scholar-Baller was always centered around the representation of student-athlete performance not only athletically, but academically as well. The connection with Myles Brand and the co-authors of the current paper is that Myles was deeply concerned about how society, especially African American communities, perceived college athletics and higher education. Scholar-Baller becoming the first image on the jersey of any NCAA athletic team was monumental on September 2, 2004 in a football contest between Arizona State University and the University of Texas-El Paso in Tempe, Arizona (the first and second authors were in attendance). With African American males highly represented in football and men's basketball at Predominantly White Institutions (PWIs), we must briefly turn our discussion to how the historical context of Black males in America as racialized bodies functions with this central question: Why do the racial aspects of the body in sport matter from a philosophical perspective?

\section{Universal Communities, Missions, and Images: Race and Philosophy}

When racial integration became legal in America in the 1950s, African American males made record demographic shifts in schools and sport. This shift resulted in an explosion of talent in the revenue-producing sports of football and men's basketball: they were considered by many as the "prized" recruits and performers and the backbone of high profile collegiate athletics (Wiggins, 1991, p. 164). However, there are perpetual challenges with the presence of Black men in starting positions at many PWIs both on macro- and micro-levels. Examining one of the pioneering philosopher's thoughts on race and prejudice might help illuminate the context of why Scholar-Baller's universal mission and images are so important for the future of African American student-athletes, including women.

Over 100 years ago, American objective idealist philosopher Josiah Royce applied his principle of loyalty to the racial climate of 1906 in his paper entitled "Race questions and prejudices." Along with W. E. B. DuBois's "The souls of Black folk" publication in 1903, Royce was among the first pragmatic philosophers to directly address issues of race in the sociopolitical context so early in the $20^{\text {th }}$ century. At a time when most White male philosophers did not take an antiracist focus, Royce stands out in writing against racism "in a time of anti-immigration and pro-imperialism sentiment due to white anxiety in the United States about the possible decline of global white supremacy" (Kegley, 2009, p. 2). His ideas on universal community building were progressive for his time: 
I also believe Royce leaves us some insights on race and race antipathies, including the lessons of his own obliviousness to the racist domination of imperialist colonialism. In advocating for loyalty to loyalty, I believe Royce would call on all persons to acknowledge the sin of racism, to overcome ignorance and recognize unconscious and conscious racism in oneself, and above all, to seek atoning deeds through communal and individual action with the goal of building a universal community which respects all persons (Kegley, 2009, p. 8).

These goals of building a universal community are embodied in the Scholar-Baller program. The program addresses the challenges of Black male athletes in revenue-generating sports on a macro-level through its value on academic excellence. It furthermore solidifies this value through the tradition of Academic All-American recognition and affirmation ceremonies. On a micro-level, Scholar-Baller engages the individual student through building an athletic community that respects all persons (Kegley, 2009). The curriculum of the program is built on principles of self-identity and social identity, which serve the overall mission of a universal community.

The goal of Scholar-Baller has always been to empower all student-athletes, especially African Americans. The resistance that this concept and movement has endured by some of the institutional and biased individual perspectives at the NCAA and some of the membership schools is part of what Professor Harry Edwards deems as the struggle that must be (Edwards, 1980). The loyalty of the first author of the current paper as a former NCAA collegiate scholar-baller himself — to give back to higher education and athletics - is the real victory and part of the lessons learned from participating in football as a center (see Figure 4 below). The irony of so much resistance is that nearly 20 years later, the Scholar-Baller patch logo represents what Myles often called "pride in the classroom" has now been imitated by numerous NCAA membership institutions. Many of these schools have even stitched the word "graduate" on their jerseys and other game attire. The next section concludes the current paper's contributions with some philosophical thoughts on Myles Brand's legacy in terms of education and sport.

\section{The Future of Dr. Myles Brand's Legacy: The Value of the NIL Movement?}

Before concluding this paper, we want to highlight some of the contributions to the literature and identify future directions for scholarship with the personal narrative, practical philosophy of the body, and somaesthetics in education and sport. One contribution is that the current paper answers the call for more action research and personal narratives in real time related to education, race, and sport - especially for African American males in the revenue sports. However, more research on the philosophy of sport and the body should be systemically dedicated to African American women and Women of Color in higher education and sport.

The personal narrative theory was utilized with two Black male voices and both have held academic appointments throughout their careers. This is important. The 


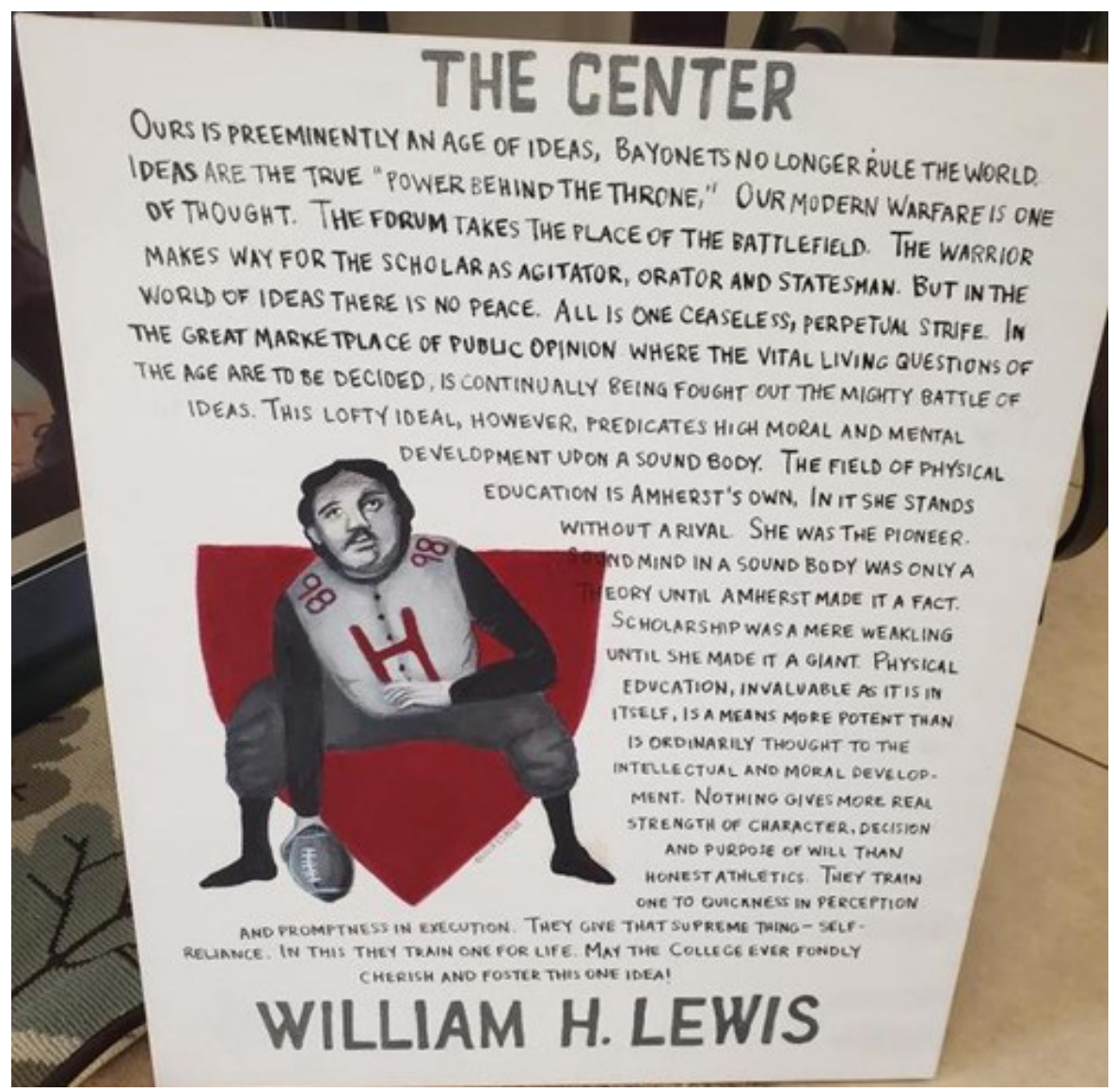

Figure 4

William Henry Lewis. Image taken from the art gallery at the Paul Robeson Research Center for Innovative Academic and Athletic Prowess at the University of Central Florida.

paper fills a gap with the dearth of Black voices and the lack of analysis of body-aesthetics in the sport philosophy literature. Furthermore, with the current racial climate of the USA during the aftermath of the post murder assassinations of Breonna Taylor and George Floyd, it is important that more personal narratives about racial educational victories be told in academic and lay platforms. The story of the first two authors in concert with the allyship of an especially influential non-Black voice (i.e., Myles Brand as a White and Jewish American) is an effective model of advocacy for racial justice that took place in real time at the nexus of NCAA, higher education, and intercollegiate athletics. Future research and theory building in the philosophy of sport as well as somaesthetics might consider the development of a subdiscipline related to intersectionality, race, and somaesthetics.

Life comes full circle: I (Keith) was a "baby professor," as Skip Gates Jr. (a notably famous Harvard professor) calls us at that stage. I first presented my phi- 
losophy of sport on Black males at a conference at Washington State University in 1996. The current paper contributes to the philosophy of the racialized body in a non-stereotypical or non-deficit perspective of Black male student-athletes through sport, which is still overlooked in many disciplines (Harrison, 1996; 1997). Finally, more research is needed on representation and performance in athletics. The story of Myles Brand in collaboration with the first two authors of the current paper is only one innovative story of academic and athletic programming success on improving academic standards through the identity formation of contemporary student-athletes. There are many others at NCAA membership institutions of higher education in North America and globally that have never been told through a philosophical and personal narrative prism.

\section{Last Words}

In the final analysis, one of the positive outcomes from the 2021 Supreme Court decision about amateurism is the attention that education-based performances in athletics have received. One Supreme Court judge asked why the NCAA \$5,980 Educational Achievement Award Stipend has not been utilized more (Lipschultz \& Bloomberg, 2021). The Name, Image and Likeness (NIL) movement intersects with more and more rights for athletes, so only time will tell how the paradigm of education and sport will shift, bend, and turn. So, what would Myles say about all these educational, social, and cultural changes that will impact intercollegiate athletics and higher education as we know it? We can only ponder, but Brand's (2006) peer-reviewed article gives us some clues as to what might be on the horizon in the good, bad, and the irreverent gray areas since the NCAA has left the NIL decisions up to each membership institution:

Students' education may include both intellectual-and physical-skill elements. Although an emphasis on the intellectual certainly has had salutary effects, a university education should not be limited in that skill development is necessarily excluded. The structure of the university, in turn, should reflect this integrated approach. On the defensive side, failure to place adequate operational controls on intercollegiate athletics is a recipe for deep problems, including public exposure by the media. On the constructive side, mainstreaming intercollegiate athletics into the campus structure is likely to yield value for the institution in terms of broadly based developmental educational opportunities (p. 18).

The lack of an integrated approach has created a perfect storm for deep biases towards physical skill development and mental accomplishments in higher education. Scholar-Baller's harmony of mind and body is a constructive approach that has continued to yield value for the institutions who maximize on this type of collaboration. Dr. Myles Brand's legacy of advocating for a sound education has a positive ripple effect for the entire campus community and macrosystem at once. Stay tuned, philosophical world. 


\section{References}

Brand, M. (2006). The role and value of intercollegiate athletics in universities. Journal of the Philosophy of Sport, 33(1), 9-20. https://doi.org/10.1080/00948705. 2006.9714687

Bronfenbrenner, U. (1979). The ecology of human development: Experiments by nature and design. Harvard University Press.

Edwards, H. (1980). The struggle that must be: An autobiography. Dorsey Press.

Harrison, C. K. (1996). Philosophy of African American males in sport. [Paper presentation]. Philosophic Society for the Study of Sport Meeting, Lewiston, Idaho.

Harrison, C. K. (1997). Philosophy of African American males in sport and society. [Paper presentation]. American Alliance for Health, Physical Education, and Dance Annual Meeting St. Louis, Missouri.

Harrison, C. K., \& Bukstein, S. (2015). College athletes in revenue and non-revenue sports: Language, culture and identity. In E. Comeaux (Ed.), Introduction to intercollegiate athletics (pp. 366-374). The John Hopkins Press.

Harrison, C. K., \& Rasmussen, J. (2015). An overview of data-informed strategies that self-affirm college athletic identities: Scholar-baller as the ideal and goal destination of success. In E. Comeaux (Ed.), Making the connection: Data-informed practices in academic support centers for college athletes (pp. 79-90). Information Age Publishing Inc.

Harrison, C. K., Saunders, R., Vincent, T., Traynowicz, L., \& Parks, C. (2018). Taking academic flight: Scholar-Baller partnerships via intercollegiate, collegiate, professional, and other brands. In D. Van Rheenan \& J. M. DeOrnellas (Eds.), Envisioning scholar-practitioner collaborations: Communities of practice in education and sport. Information Age Publishing Inc.

Harrison, C. K., \& Sutton, W. A. (2013). Cracking their world: Utilizing pop culture to impact academic success of today's student-athlete. In D. Brooks \& R. Althouse (Eds.), Racism in college athletics ( $3^{\text {rd }}$ ed., pp. 255-267). Fitness Information Technology Inc.

Harrison, C. K., Vincent, T. A., Saunders, R., \& Parks, C. (2020). The culture of today's ballplayers and ballin' images: African American (Black) manhood in a hip hop world. In D. Brooks \& R. Althouse (Eds.), Racism in college athletics ( $4^{\text {th }}$ ed., pp. 311-320). Fitness Information Technology Inc.

Kegley, J. A. K. (2009). Josiah Royce on race: Issues in context. The Pluralist, 4(3), 1-9. https://doi.org/10.1353/plu.0.0025

Kohler-Riessman, C. (2001). Analysis of personal narratives. In J. F. Gubrium \& J. A. Holstein (Eds.), Handbook of interview research (pp. 367-380). SAGE Publications, Inc. https://www.doi.org/10.4135/9781412973588.n40

Kretchmar, R. S. (1994). Practical philosophy of sport. Human Kinetics.

Laslett, B. (1999). Personal narratives as sociology. Contemporary Sociology, 28(4), 391-401. https://doi.org/10.2307/2655287

Lipschultz, B., \& Bloomberg, B. (2021, June 23). "NCAA Supreme Court ruling threatens to further divide the haves and have-nots of college sports." Fortune. 
https://fortune.com/2021/06/23/ncaa-supreme-court-ruling-division-i-studentathletes-college-sports/

McAdams, D. P. (2008). Personal narratives and the life story. In O. John, R. Robins, $\&$ L. Pervin (Eds.), Handbook of personality: Theory and research ( $3^{\text {rd }} \mathrm{ed}$., pp. 242-262). The Guilford Press.

Scholarballer.org. (n.d.). Scholar baller home. http://scholarballer.org/

Shusterman, R. (1999). Somaesthetics: A disciplinary proposal. The Journal of Aesthetics and Art Criticism, 57(3), 299-313. https://doi.org/10.2307/432196

Singer, J. (2016). African American male college athletes' narratives on education and racism. Urban Education, 51(9), 1065-1095. https://doi. org/10.1177/0042085916669749

Weiser, P. B. (in press). Changing perceptions of beautiful bodies: The athletics agency model. In A. Edgar \& W. J. Morgan (Eds.), Somaesthetics and sport. Brill Press.

Wiggins, D. (1991). Prized performers, but frequently overlooked students: The involvement of Black athletes in intercollegiate sports on predominantly White university campuses, 1890-1972. Research Quarterly for Exercise and Sport, 62(2), 164-177. https://doi.org/10.1080/02701367.1991.10608707 